\title{
First cytogenetic information for Drymoreomys albimaculatus (Rodentia, Cricetidae), a recently described genus from Brazilian Atlantic Forest
}

\author{
Elkin Y. Suárez-Villota', Camilla B. Di-Nizo', \\ Carolina L. Neves², Maria José de Jesus Silva' \\ I Laboratório de Ecologia e Evolução, Instituto Butantan, São Paulo, Brazil 2 Laboratório de Biologia da \\ Conservação, Departamento de Ecologia, Universidade Estadual Paulista (UNESP), Rio Claro, SP, Brazil \\ Corresponding author: Maria José de Jesus Silva (mariajo@butantan.gov.br)
}

Academic editor: K. M. Helgen | Received 19 February 2013 | Accepted 15 May 2013 | Published 21 May 2013

Citation: Suárez-Villota EY, Di-Nizo CB, Neves CL, Silva MJJ (2013) First cytogenetic information for Drymoreomys albimaculatus (Rodentia, Cricetidae), a recently described genus from Brazilian Atlantic Forest. ZooKeys 303: 65-76. doi: $10.3897 /$ zookeys.303.4873

\begin{abstract}
The recently described taxon Drymoreomys albimaculatus is endemic to the Brazilian Atlantic Forest and its biology and genetics are still poorly known. Herein, we present, for the first time, the karyotype of the species using classical and molecular cytogenetics, which showed $2 \mathrm{n}=62, \mathrm{FN}=62$, and interstitial telomeric signals at the sex chromosomes. Nuclear and mitochondrial DNA sequences from the two karyotyped individuals verify the taxonomic identity as the recently described D. albimaculatus and confirm the relationship of the species with other Oryzomyini. Additionally, external morphological information is provided.
\end{abstract}

\section{Keywords}

Oryzomyini, karyotype, CBG banding, GTG banding, FISH, IRBP, Cyt $b$

\section{Introduction}

The Atlantic Forest harbors a high diversity of mammals, 20 percent of which are rodents of the subfamily Sigmodontinae (Ribeiro et al. 2009). However, the fauna of this biome is still barely known, such that discovery of new species is still common (De 
Vivo et al. 2010). Since 1999, 14 new species of sigmodontines were formally described for Atlantic Forest: Abrawayaomys chebezi (Pardiñas et al. 2009), Akodon paranaensis (Christoff et al. 2000), A. philipmeyersi (Pardiñas et al. 2005), A. reigi (González et al. 1999), Brucepattersonius paradisus, B. guarani, B. misionensis (Mares and Braun 2000), Cerradomys langguthi, C. vivoi (Percequillo et al. 2008), Hylaeamys seuanezi (Weksler et al. 1999), Juliomys rimofrons (Oliveira and Bonvicino 2002), J. ossitenius (Costa et al. 2007), Rhipidomys tribei, and R. itoan (Costa et al. 2011).

Recently, Percequillo et al. (2011) described Drymoreomys albimaculatus as a new monotypic genus, endemic to the Brazilian Atlantic Forest and known from a few localities in São Paulo and Santa Catarina states. Phylogenetic analyses based on morphological traits and DNA sequences [1143bp of cytochrome $b$ (Cyt $b$ ) and 1235bp of interphotoreceptor retinoid binding protein (IRBP) genes] revealed the placement of $D$. albimaculatus in the tribe Oryzomyini, raising to 30 the number of extant Oryzomyini genera. According to those analyses, Percequillo et al. (2011) revealed that $D$. albimaculatus is the sister species of the Andean rat Eremoryzomys polius.

Here, we describe the karyotype of $D$. albimaculatus for the first time. In order to investigate the molecular identification of the two karyotyped animals, we added its Cyt $b$ and IRBP sequences to the molecular data published by Percequillo et al. (2011). Additionally, we present morphological comments on the specimens.

\section{Material and methods}

\section{Sampling}

One male and one female were collected with pitfall traps in Santa Virgínia, Parque Estadual da Serra do Mar $\left[45^{\circ} 03.00^{\prime}\right.$ to $45^{\circ} 11.00^{\prime} \mathrm{W}$ (DDM); $23^{\circ} 24.00^{\prime}$ to $23^{\circ} 17.00^{\prime} \mathrm{S}$ $(\mathrm{DDM})]$, state of São Paulo, Brazil. Pelage color and external measurements were taken during the fieldwork. Vouchers of both individuals are deposited in the Coleção de Mamíferos da Universidade Federal do Espírito Santo (UFES) under the catalog numbers UFES 2271 and UFES 2272.

\section{Cytogenetic analyses}

Metaphases were obtained in vivo from spleen and bone marrow, according to Ford and Hamerton (1956) with modifications. Conventional Giemsa staining was used to determine the diploid (2n) and the number of autosome arms (FN). GTG and CBG-banding were performed according to Seabright (1971) and Sumner (1972), respectively, with modifications. Fluorescent in situ hybridization (FISH) with a FITC labeled $\left(\mathrm{C}_{3} \mathrm{TA}_{2}\right)_{n}$ peptide nucleic acid (PNA) probe (DAKO) was carried out following the recommended protocol (Telomere PNA FISH Kit/FITC, Code No. K5325, DAKO). Mitotic plates were digitally captured with visible light or blue and green 
filters (emission at 461 and $517 \mathrm{~nm}$, respectively) in an Axioskop 40 epifluorescence microscope (Carl Zeiss) equipped with an Axiocam camera and AxionVision software. Images were overlaid and contrast enhanced with Adobe Photoshop CS5.1.

\section{DNA extraction, amplification, and sequencing}

DNA was extracted from liver with Chelex 5\% (Bio-Rad) following Walsh et al. (1991). Amplification of an $820 \mathrm{bp}$ fragment of Cyt $b$ and a $782 \mathrm{bp}$ of IRBP was performed with PCR using primers MVZ5 and MVZ16 (Irwin et al. 1991; Smith and Patton 1993), and A1 and F (Stanhope et al. 1992), respectively. Both extraction and PCR controls were used for each amplification. Each PCR mixture had $30 \mathrm{ng}$ of DNA, $25 \mathrm{pmol}$ of each primer, $0.2 \mathrm{mM}$ of dNTP, and $2.52 \mu \mathrm{L}$ of reaction buffer $(50 \mathrm{mM} \mathrm{KCl}, 2.5 \mathrm{mM}$ $\mathrm{MgCl} 2,10 \mathrm{mM}$ Tris-HCl; $\mathrm{pH} 8.8$ ), and 0.2 units of Taq DNA polymerase (Invitrogen) were added to complete $18 \mu \mathrm{L}$. Forty amplification cycles were performed in a thermal cycler (Eppendorf Mastercycler ep Gradient, Model 5341). Each cycle consisted of denaturation at $94^{\circ} \mathrm{C}$ for $30 \mathrm{~s}$, annealing at $48^{\circ} \mathrm{C}$ for $45 \mathrm{~s}$, and extension at $72^{\circ} \mathrm{C}$ for $45 \mathrm{~s}$ for Cyt $b$, and denaturation at $94^{\circ} \mathrm{C}$ for $30 \mathrm{~s}$, annealing at $60^{\circ} \mathrm{C}$ for $60 \mathrm{~s}$, and extension at $72^{\circ} \mathrm{C}$ for $180 \mathrm{~s}$ for IRBP. A final extension at $72^{\circ} \mathrm{C}$ for $5 \mathrm{~min}$ was performed for both Cyt $b$ and IRBP amplifications. The PCR products were separated using $1 \%$ agarose gels in TAE buffer. Nucleotide sequencing was conducted using BigDye Terminator v3.1 Cycle Sequencing Kit (Applied Biosystems) and an ABI PRISM 3100 Genetic Analyzer (Applied Biosystems). Sequences of each animal were aligned with sequences from previously published data deposited on GenBank by Bonvicino and Moreira (2001), Weksler (2003), and Percequillo et al. (2011) using MAFFT ver. 5 (Katoh et al. 2005) under the iterative method of global pairwise alignment (G-INS-i). Our sequences were submitted to GenBank under accession numbers KF031014-KF031017.

\section{Phylogenetic analyses}

We performed maximum likelihood (ML) and Bayesian analyses using concatenated Cyt b-IRBP data set. For both analyses we used gene-specific unlinked models. The best-fitting model of nucleotide substitution for each gene was selected using the Akaike information criterion in accordance with the procedure outlined by Posada and Buckley (2004), and implemented in jModelTest, version 0.1.1 (Posada 2008). The maximum-likelihood trees were calculated using RAxML (Stamatakis 2006). The statistical support for the nodes was estimated by the nonparametric bootstrap, with 1000 pseudoreplicates (Felsenstein 1985). Bayesian analysis was performed using $\mathrm{Mr}$ Bayes 3.04b (Ronquist and Huelsenbeck 2003). Markov chains were started from a random tree and run for $1.0 \times 10^{7}$ generations, sampling every 1000th generation. The stationary phase was checked following Nylander et al. (2004). Sample points prior to the plateau phase were discarded as burn-in, and the remaining trees were combined to 
find the maximum a posteriori probability estimated of the phylogeny. Branch support was estimated by Bayesian posterior probabilities (BPP). Two simultaneous analyses were performed to ensure convergence on topologies.

\section{Results}

\section{Cytogenetic analyses}

The animals showed $2 \mathrm{n}=62, \mathrm{FN}=62$, and the autosome set composed of 29 acrocentric pairs decreasing in size, and one small metacentric pair (Fig. 1A). The $\mathrm{X}$ is a large submetacentric, and the $\mathrm{Y}$ is a large submetacentric slightly smaller than the $\mathrm{X}$ (Fig. 1A). CBG-banding revealed pericentromeric constitutive heterochromatic blocks in all autosomes and in the long arm of Y (Fig. 1B). GTG-banding allowed the identification of almost all autosomic pairs, the $\mathrm{X}$ chromosome exhibited two interstitial bands at the long arm while a conspicuous pattern in the $Y$ was not found (Fig. 1C). FISH detected telomeric signals at the ends of all chromosomes and additional telomeric sequences were found in the pericentromeric region of both $\mathrm{X}$ and $\mathrm{Y}$ chromosomes (Fig. 1D).

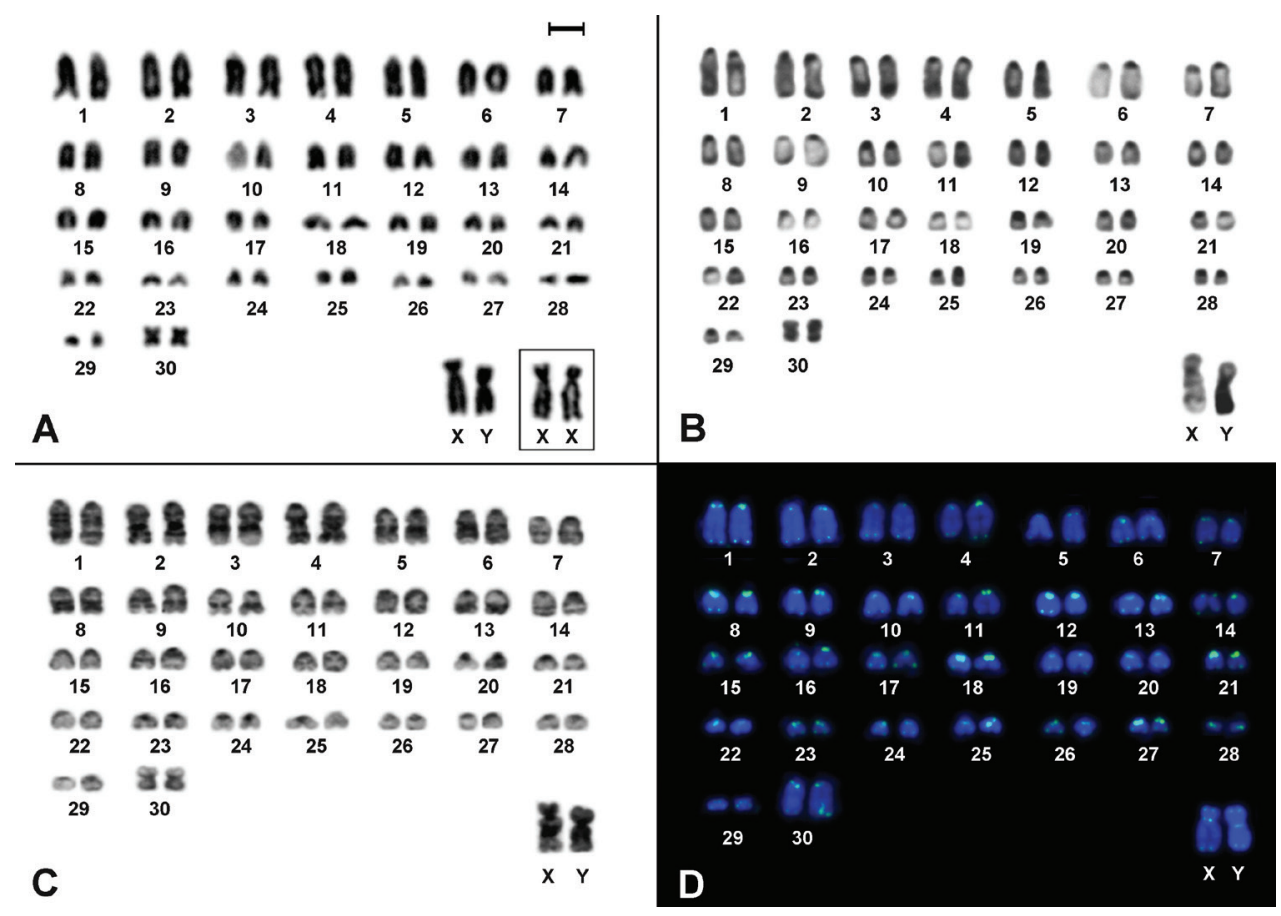

Figure I. Cytogenetic analyses in Drymoreomys albimaculatus from Santa Virgínia, state of São Paulo, Brazil. A Karyotype of male $(2 \mathrm{n}=62, \mathrm{FN}=62)$, after conventional staining. Inset: sex chromosomes of a female B CBG-banding of a male C GTG-banding of a male D Fluorescent in situ hybridization using telomeric PNA probe over male mitotic plates. Bar scale $=10 \mu \mathrm{m}$. 


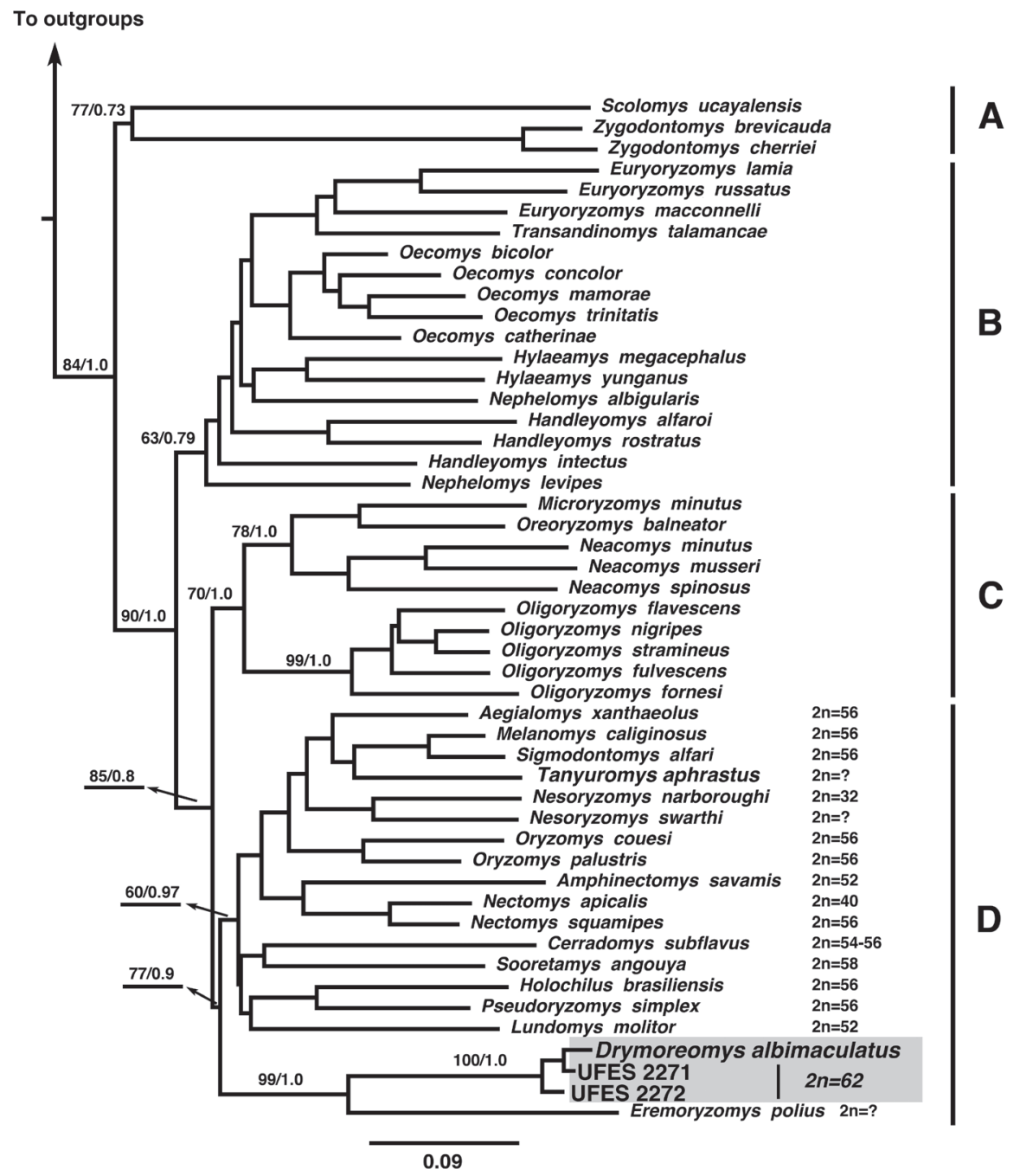

Figure 2. Maximum likelihood tree of combined molecular datasets [cytochrome b (Cyt $b$ ), interphotoreceptor retinoid binding protein (IRBP)] using Santa Virgínia specimens (UFES2271, UFES2272). Bootstrap nodal support indices and Bayesian posterior probabilities are shown above the branches, respectively. Outgroups include Peromyscus maniculatus (Neotominae); Nyctomys sumichrasti (Tylomyinae), Delomys sublineatus (Sigmodontinae), Thomasomys baeops (Sigmodontinae), and Wiedomys pyrrhorhinos (Sigmodontinae). Available diploid numbers (2n) of clade D are indicated (for details see Table 1), although the lowest diploid number (Nectomys palmipes, $2 \mathrm{n}=16$, Barros et al. 1992) does not appear in the figure.

\section{Phylogenetic analyses}

The model selected for the phylogenetic analyses (ML and Bayesian) was GTR $+\mathrm{I}+\Gamma$ for each gene. The best ML tree had a - ln likelihood score of -22,345.02. The Bayesian analysis recovered a consensus topology similar to the best ML tree and the results recovered the four well-supported clades A, B, C, and D (Fig. 2) previously reported 
by Weksler (2006) and Percequillo et al. (2011). In both phylogenetic analyses, Santa Virgínia specimens (UFES 2271 and UFES 2272) clustered with high statistical support to the recently described $D$. albimaculatus (Fig. 2, grey area).

\section{Discussion}

Phylogenetic analyses (ML and Bayesian) recovered the four clades A, B, C, and D (Fig. 2) recovered by Weksler (2006) and Percequillo et al. (2011). In both phylogenetic reconstructions, Santa Virgínia specimens were recovered with high statistical support in clade $\mathrm{D}$, confirming their identity as $D$. albimaculatus (Fig. 2, grey area), and consistent with Percequillo et al. (2011). Our analyses also recovered D. albimaculatus as the sister species of Eremoryzomys polius and both species diverged early in the clade D (Fig. 2).

The diploid number of $D$. albimaculatus corroborates the pattern found for the majority of the Oryzomyini species, in which karyotypes present relatively high chromosome number and predominantly acrocentric pairs. The typical heterochromatic pattern of sex chromosomes is also found in most of the oryzomyine species and it is an essential condition for the recognition of the $Y$ (Fig. 1B).

The karyotype herein reported for $D$. albimaculatus is species-specific, since only three other Oryzomyini species present the same diploid number, but different FN: Oligoryzomys fornesi $(2 \mathrm{n}=62, \mathrm{FN}=64)$, Oligoryzomys delicatus $(2 \mathrm{n}=62, \mathrm{FN}=74$ and 76$)$, and Oligoryzomys nigripes $(2 \mathrm{n}=62, \mathrm{FN}=80,81$ and 82) (Gardner and Patton 1976; Weksler and Bonvicino 2005). Telomeric sequences at the pericentromeric region of D. albimaculatus' sex chromosomes could be hypothesized as (i) similar to regular sequences of the centromeres, (ii) related to a amplification of $\left(\mathrm{T}_{2} \mathrm{AG}_{3}\right)_{\mathrm{n}}$-like satellite DNA repeats, or (iii) resulted of a structural rearrangement. In fact, interstitial telomeric sequences are common in vertebrates (Meyne et al. 1990) and apparently are a structural component of mammalian satellite DNA (Garagna et al. 1997; Pagnozzi et al. 2000). Additionally, these sequences have been associated with chromosome rearrangements (Ruiz-Herrera et al. 2008; Bolzan 2012).

A compilation of karyological studies in representative species of clade $\mathrm{D}$ is presented in Table 1. Notably, cytogenetic data in Oryzomyini has increased considerably in the last decades, mainly because the karyotype has become a valid tool for identifying species of this group. Although several species still remain without karyotypic information (e.g., Eremoryzomys polius, Tanyuromys aphrastus, Nesoryzomys swarthy), the diploid number within clade D varies from 16 in Nectomys palmipes (Barros et al. 1992) to 62 in D. albimaculatus. As D. albimaculatus exhibited the highest diploid number reported hitherto and diverged early in clade $\mathrm{D}$, karyotype evolution in this clade based on the phylogeny (Fig. 2), apparently exhibits a trend toward a decrease in the diploid number. This hypothesis could imply chromosomal plasticity in low $2 \mathrm{n}$ ratios as suggested by Gardner and Patton (1976). In this sense, tandem fusions have perhaps played significant role in clade $\mathrm{D}$, resulting in the lower diploid numbers. Robersonian rearrangements could have occurred in this group as well, since some species of clade 


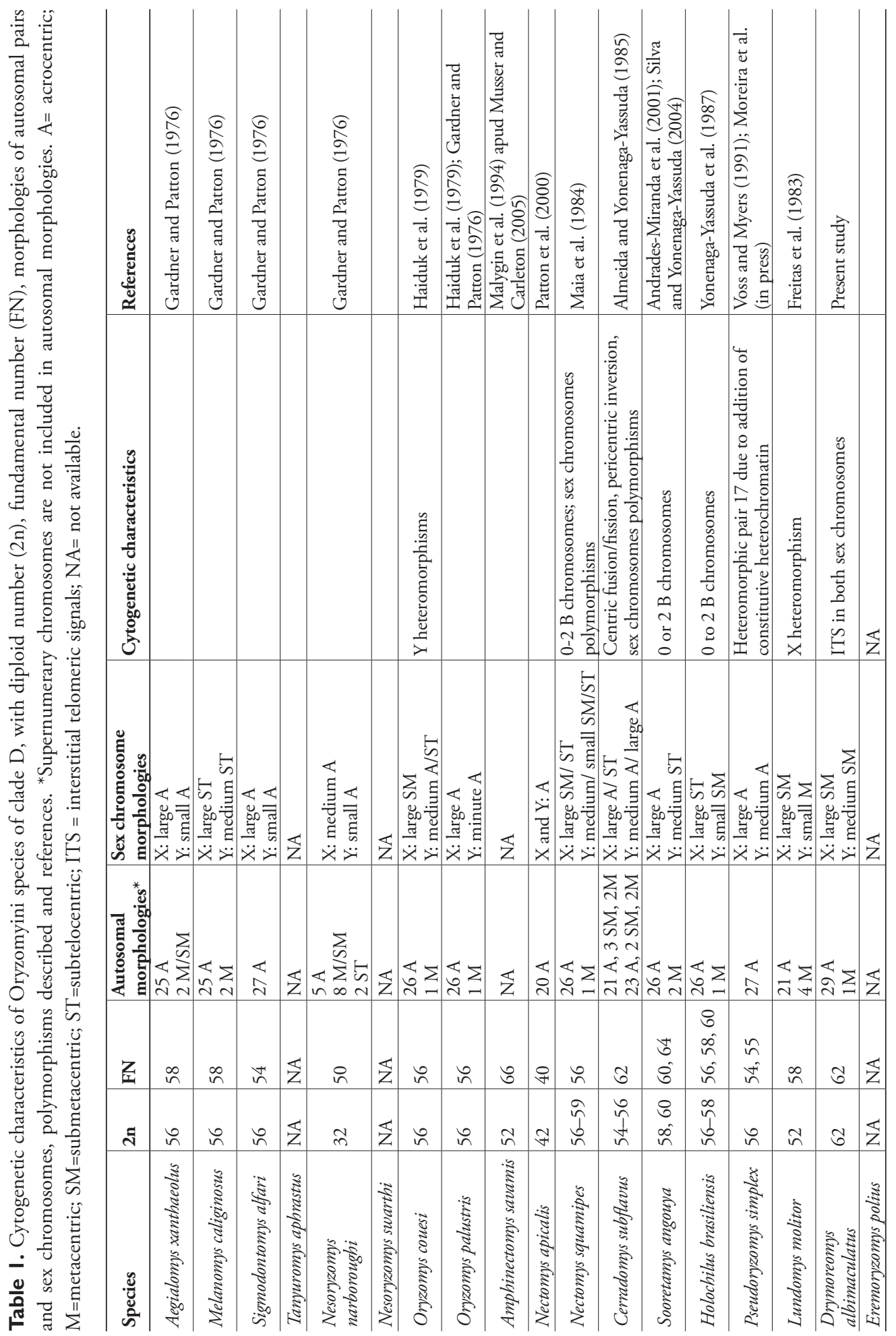


D present the same FN but different $2 \mathrm{n}$ and number of biarmed chromosomes (e.g., D. albimaculatus and Cerradomys subflavus, Table 1). Non-Robertsonian mechanisms such as pericentric inversions, unequal translocations, or whole-arm heterochromatin addition or deletion could also be invoked in those cases of changes in FN but not in $2 \mathrm{n}$ (e.g., Sigmodontomys alfari, and Melanomys caliginous, Table 1).

Species of clade D present sex and supernumerary chromosomes easily identifiable with classical cytogenetic approaches, and some species exhibit sex chromosomes with polymorphisms/heteromorphisms and interstitial telomeric signals (ITS; Table 1, Fig. 1D). Thus, this clade is an excellent model to study origin, evolution, and chromatin composition of these chromosomes. For instance, a superficial morphological comparison among sex chromosomes from Table 1 could suggest the occurrence of pericentric inversions, or whole-arm heterochromatin additions or deletions.

\section{Comments on external morphology and natural history}

The specimens collected were medium sized (male body mass: $46.5 \mathrm{~g}$, head and body length: $115 \mathrm{~mm}$, and tail length: $142 \mathrm{~mm}$; female body mass: $57 \mathrm{~g}$, head and body length: $127 \mathrm{~mm}$, and tail length: $170 \mathrm{~mm}$ ). Tail was longer than head and body, and was a uniform color on both sides. Male hind foot was short $(25 \mathrm{~mm}, 22 \%$ of head and body length) and ears were small (16 mm; 14\% of head and body length). These external morphological measures overlapped with those of the Drymoreomys albimaculatus holotype (Percequillo et al. 2011). Dorsal pelage was reddish-brown; ventral pelage was predominantly grayish. Samples exhibited the pattern of short hind feet consistent with Oecomys. Fore and hind feet digits were covered by silvery-white hairs and the dorsal surface of hind feet were covered by brown hairs forming a patch, in a more conspicuous pattern than the observed for Rhipidomys. Thus, some external morphological traits were similar to those described for Rhipidomys and Oecomys as reported Percequillo et al. (2011). Nevertheless, our samples exhibited the characteristics of the D. albimaculatus holotype that differentiate it from Rhipidomys, such as the shorter, thinner, and sparser mystacial vibrissae and presence of gular to pectoral patches of white hair. Additionally, we detected that, contrary to what is found in Rhipidomys, a tuft of hairs on the tail's end is absent in our samples. On the other hand, several anatomical traits that distinguish the Drymoreomys albimaculatus holotype and species of Oecomys were observed in our samples, such as the plantar surface of pes covered with squamae; dorsal surface of pes with dark patches of brown hairs and the ventral pelage with gular and thoracic white patches (Percequillo et al. 2011).

Percequillo et al. (2011) reported that most of the Drymoreomys specimens were collected in pitfall traps; in the present work, the animals were also collected in the same way. These reiterate the importance of further fieldwork effort, with different collecting methods in order to increase the spectrum of small mammals collected. Consequently, our knowledge of small mammal biodiversity will be improved as a whole, which will allow improvements in relevant laws and policies for biodiversity protection. 


\section{Acknowledgments}

This work was supported by FAPESP (2008/00493-9 and 2010/03432-0 for CDN, Jovem Pesquisador 2005/04557-3 for MJJS), CNPq (131891/2008-1 for CLN) and by CONICYT (Becas Chile 74130017 for EYSV). We thank two anonymous reviewers for their helpful comments.

\section{References}

Almeida EJC, Yonenaga-Yassuda Y (1985) Robertsonian fusion, pericentric inversion and sexchromosome heteromorphisms in Oryzomys subflavus (Cricetidae, Rodentia). Caryologia 38: 129-137.

Andrades-Miranda J, Zanchin NIT, Oliveira LFB, Langguth AR, Mattevi MS (2001) Cytogenetic studies in nine taxa of the genus Oryzomys (Rodentia, Sigmodontinae) from Brazil. Mammalia 65: 461-472. doi: 10.1515/Mamm.2001.65.4.461

Barros MA, Reig OA, Perez-Zapata A (1992) Cytogenetics and karyosystematics of South American Oryzomyine rodents (Cricetidae, Sigmodontinae). Cytogenetics and Cell Genetics 59: 34-38. doi: 10.1159/000133195

Bolzan AD (2012) Chromosomal aberrations involving telomeres and interstitial telomeric sequences. Mutagenesis 27: 1-15.

Bonvicino CR, Moreira MA (2001) Molecular phylogeny of the genus Oryzomys (Rodentia: Sigmodontinae) based on cytochrome $b$ DNA sequences. Molecular Phylogenetics and Evolution 18: 282-292. doi: 10.1006/mpev.2000.0878

Christoff AU, Fagundes V, Sbalqueiro IJ, Mattevi MS, Yonenaga-Yassuda Y (2000) Description of a new species of Akodon (Rodentia: Sigmodontinae) from southern Brazil. Journal of Mammalogy 81: 838-851. doi: 10.1644/1545-1542(2000)081<0838:Doanso >2.3. $\mathrm{Co} ; 2$

Costa BMDA, Geise L, Pereira LG, Costa LP (2011) Phylogeography of Rhipidomys (Rodentia: Cricetidae: Sigmodontinae) and description of two new species from southeastern Brazil. Journal of Mammalogy 92: 945-962. doi: 10.1644/10-mamm-a-249.1

Costa LP, Pavan SE, Leite YLR, Fagundes V (2007) A new species of Juliomys (Mammalia: Rodentia: Cricetidae) from the Atlantic forest of southeastern Brazil. Zootaxa 1463: 21-37. doi: $10.2307 / 2806242$

De Vivo M, Carmignotto AP, Gregorin R, Hingst-Zaher E, Lack-Ximenes GE, Miretzki M, Percequillo AR, Rollo-Jr MM, Rossi RV, Taddei VA (2010) Checklist of mammals from São Paulo State, Brazil. Biota Neotropica http://www.biotaneotropica.org.br/v11n1a/pt/ abstract?inventory+bn0071101a2011

Felsenstein J (1985) Confidence limits on phylogenies: an approach using the bootstrap. Evolution 39: 783-791. doi: 10.2307/2408678

Ford CE, Hamerton JL (1956) A colchicine, hypotonic citrate, squash sequence for mammalian chromosomes. Stain Technology 31: 247-251. doi: 10.3109/10520295609113814 
Freitas TRO, Mattevi MS, Oliveira LFB, Souza MJ, Yonenaga-Yassuda Y, Salzano FM (1983) Chromosome relationships in three representatives of the genus Holochilus (Rodentia, Cricetidae) from Brazil. Genetica 61: 13-20. doi: 10.1007/bf00563228

Garagna S, Ronchetti E, Mascheretti S, Crovella S, Formenti D, Rumpler Y, Manfredi Romanini MG (1997) Non-telomeric chromosome localization of (TTAGGG) repeats in the genus Eulemur. Chromosome Research 5: 487-491. doi: 10.1023/A:1018425215516

Gardner AL, Patton JL (1976) Karyotypic variation in Oryzomyine Rodents (Cricetinae) with comments on chromosomal evolution in the neotropical Cricetine Complex. Occasional Papers of the Museum of Zoology, Louisiana State University 49: 1-47.

González EM, Langguth A, Oliveira LF (1999) A new species of Akodon from Uruguay and southern Brazil: (Mammalia: Rodentia: Sigmodontinae). Comunicaciones Zoológicas del Museo de Historia Natural de Montevideo 191: 1-8.

Haiduk MW, Bickham JW, Schmidly DJ (1979) Karyotypes of six species of Oryzomys from Mexico and Central America. Journal of Mammalogy 60: 610-615. doi: 10.2307/1380103 Irwin DM, Kocher TD, Wilson AC (1991) Evolution of the cytochrome $b$ gene of mammals. Journal of Molecular Evolution 32: 128-144. doi: 10.1007/BF02515385

Katoh K, Kuma K, Toh H, Miyata T (2005) MAFFT version 5: improvement in accuracy of multiple sequence alignment. Nucleic Acids Research 33: 511-518. doi: 10.1093/nar/ gki198

Maia V, Yonenaga-Yassuda Y, Freitas TRO, Kasahara S, Sune-Mattevi M, Oliveira LF, Galindo MA, Sbalqueiro IJ (1984) Supernumerary chromosomes, robertsonian rearrangement and variability of the sex-chromosomes in Nectomys squamipes (Cricetidae, Rodentia). Genetica 63: 121-128. doi: 10.1007/Bf00605896

Malygin VM, Aniskin VM, Isaev SI, Milishnikov AN (1994) Amphinectomys savamis Malygin Gen-N Et Sp-N, a new genus and a new species of water rat (Cricetidae, Rodentia) from Peruvian Amazonia. Zoologichesky Zhurnal 73: 195-208.

Mares MA, Braun JK (2000) Three new species of Brucepattersonius (Rodentia: Sigmodontinae) from Misiones Province, Argentina. Occasional Papers of the Sam Noble Oklahoma Museum of Natural History 9: 1-3.

Meyne J, Baker RJ, Hobart HH, Hsu TC, Ryder OA, Ward OG, Wiley JE, Wurster-Hill DH, Yates TL, Moyzis RK (1990) Distribution of non-telomeric sites of the (TTAGGG) telomeric sequence in vertebrate chromosomes. Chromosoma 99: 3-10. doi: 10.1007/ BF01737283

Moreira CN, Di-Nizo CB, Silva MJJ, Yonenaga-Yassuda Y, Ventura K (in press) A remarkable autosomal heteromorphism in Pseudoryzomys simplex $2 \mathrm{n}=56, \mathrm{NFa}=54,55$ (Rodentia, Sigmodontinae). Genetics and Molecular Biology.

Musser GG, Carleton MD (2005) Superfamily Muroidea. In: Wilson DE, Reeder DM (Eds) Mammal Species of the World: A Taxonomic and Geographic Reference. John Hopkins University Press, Baltimore, 894-1531.

Nylander JA, Ronquist F, Huelsenbeck JP, Nieves-Aldrey JL (2004) Bayesian phylogenetic analysis of combined data. Systematic Biology 53: 47-67. doi: 10.1080/10635150490264699

Oliveira JA, Bonvicino CR (2002) A new species of sigmodontine rodent from the Atlantic forest of eastern Brazil. Acta Theriologica 47: 307-322. doi: 10.1007/BF03194149 
Pagnozzi JM, Silva MJJ, Yonenaga-Yassuda Y (2000) Intraspecific variation in the distribution of the interstitial telomeric (TTAGGG) sequences in Micoureus demerarae (Marsupialia: Didelphidae). Chromosome Research 8: 585-591. doi: 10.1023/A:1009229806649

Pardińas UFJ, D’Elia G, Cirignoli S, Suarez P (2005) A new species of Akodon (Rodentia, Cricetidae) from the northern campos grasslands of Argentina. Journal of Mammalogy 86: 462-474. doi: 10.1644/1545-1542(2005)86[462:Ansoar]2.0.Co;2

Pardiñas UFJ, Teta P, D’Elia G (2009) Taxonomy and distribution of Abrawayaomys (Rodentia: Cricetidae), an Atlantic Forest endemic with the description of a new species. Zootaxa: 39-60. doi: 10.11646/zootaxa.3641.4.9

Patton JL, Da Silva MNF, Malcolm JR (2000) Mammals of the Rio Juruá and the evolutionary and ecological diversification of Amazonia. Bulletin of the American Museum of Natural History 244: 1-306. doi: 10.1206/0003-0090(2000)244<0001:motrja>2.0.co;2

Percequillo AR, Hingst-Zaher E, Bonvicino CR (2008) Systematic review of genus Cerradomys Weksler, Percequillo and Voss, 2006 (Rodentia: Cricetidae: Sigmodontinae: Oryzomyini), with description of two new species from eastern Brazil. American Museum Novitates: 1-46. doi: 10.1206/495.1

Percequillo AR, Weksler M, Costa LP (2011) A new genus and species of rodent from the Brazilian Atlantic Forest (Rodentia: Cricetidae: Sigmodontinae: Oryzomyini), with comments on oryzomyine biogeography. Zoological Journal of Linnean Society 161: 357-390. doi: 10.1111/j.1096-3642.2010.00643.x

Posada D (2008) jModelTest: phylogenetic model averaging. Molecular Biology and Evolution 25: 1253-1256. doi: 10.1093/molbev/msn083

Posada D, Buckley TR (2004) Model selection and model averaging in phylogenetics: advantages of akaike information criterion and bayesian approaches over likelihood ratio tests. Systematic Biology 53: 793-808. doi: 10.1080/10635150490522304

Ribeiro MC, Metzger JP, Martensen AC, Ponzoni FJ, Hirota MM (2009) The Brazilian Atlantic Forest: how much is left, and how is the remaining forest distributed? Implications for conservation. Biological Conservation 142: 1141-1153. doi: 10.1016/J.Biocon.2009.02.021

Ronquist F, Huelsenbeck JP (2003) MrBayes 3: Bayesian phylogenetic inference under mixed models. Bioinformatics 19: 1572-1574. doi: 10.1093/bioinformatics/btg180

Ruiz-Herrera A, Nergadze SG, Santagostino M, Giulotto E (2008) Telomeric repeats far from the ends: mechanisms of origin and role in evolution. Cytogenetic and Genome Research 122: 219-228. doi: 10.1159/000167807000167807

Seabright M (1971) A rapid banding technique for human chromosomes. Lancet 2: 971-972. doi: 10.1016/S0140-6736(71)90287-X

Silva MJJ, Yonenaga-Yassuda Y (2004) B chromosomes in Brazilian rodents. Cytogenetic and Genome Research 106: 257-263. doi: 10.1159/000079296

Smith MF, Patton JL (1993) The diversification of South American murid rodents: evidence from mitochondrial DNA sequence data for the Akodontine tribe. Biological Journal of the Linnean Society 50: 149-177. doi: 10.1111/J.1095-8312.1993.Tb00924.X

Stamatakis A (2006) RAxML-VI-HPC: maximum likelihood-based phylogenetic analyses with thousands of taxa and mixed models. Bioinformatics 22: 2688-2690. doi: 10.1093/bioinformatics/btl446 
Stanhope MJ, Czelusniak J, Si JS, Nickerson J, Goodman M (1992) A molecular perspective on mammalian evolution from the gene encoding interphotoreceptor retinoid binding protein, with convincing evidence for bat monophyly. Molecular Phylogenetics and Evolution 1: 148-160. doi: 10.1016/1055-7903(92)90026-D

Sumner AT (1972) A simple technique for demonstrating centromeric heterochromatin. Experimental Cell Research 75: 304-306.

Voss RS, Myers P (1991) Pseudoryzomys simplex (Rodentia, Muridae) and the significance of lund collections from the caves of Lagoa-Santa, Brazil. Bulletin of the American Museum of Natural History: 414-432.

Walsh PF, Metzger DA, Higuchi R (1991) Chelex 100 as a medium for simple extraction of DNA for PCR-based typing from forensic material. Biotechniques 10: 506-513.

Weksler M (2003) Phylogeny of Neotropical oryzomyine rodents (Muridae: Sigmodontinae) based on the nuclear IRBP exon. Molecular Phylogenetics and Evolution 29: 331-349.

Weksler M (2006) Phylogenetic relationships of oryzomine rodents (Muroidea: Sigmodontinae): separate and combined analyses of morphological and molecular data. Bulletin of the American Museum of Natural History 296: 1-48.

Weksler M, Bonvicino CR (2005) Taxonomy of pigmy rice rats genus Oligoryzomys Bangs, 1900 (Rodentia, Sigmodontinae) of the Brazilian Cerrado, with the description of two new species. Arquivos do Museu Nacional Rio de Janeiro 63: 113-130.

Weksler M, Geise L, Cerqueira R (1999) A new species of Oryzomys (Rodentia, Sigmondontinae) from southeast Brazil, with comments on the classification of the O. capito species group. Zoological Journal of the Linnean Society 125: 445-462. doi: 10.1111/J.10963642.1999.Tb00600.X

Yonenaga-Yassuda Y, Prado RCD, Mello DA (1987) Supernumerary chromosomes in Holochilus brasiliensis and comparative cytogenetic analysis with Nectomys squamipes (Cricetidae, Rodentia). Revista Brasileira de Genetica 10: 209-220. 